\title{
EFFECTS OF IRRIGATION, PLANTATION DENSITY AND CLONAL COMPOSITION ON WOODY BIOMASS QUALITY FOR BIOENERGY IN A SHORT ROTATION CULTURE SYSTEM WITH WILLOWS (Salix spp.) ${ }^{1}$
}

\author{
Fabio Germán Achinelli², Guillermo Doffo ${ }^{3}$, Antonio José Barotto ${ }^{3}$, Virginia Luquez ${ }^{3}$ and Silvia \\ Monteoliva $^{4}$
}

\footnotetext{
${ }^{1}$ Received on 07.06.2017 accepted for publication on 07.05.2018.

${ }^{2}$ Universidad Nacional de La Plata, Comisión de Investigaciones Científicas, Buenos Aires, Argentina. E-mail: $<$ fachinell@agro.unlp.edu.ar>.

${ }^{3}$ Instituto de Fisiologia Vegetal, UNLP-CONICET, Argentina. E-mail: <guilledoffo@ gmail.com>, <jbarotto@ conicet.gov.ar> and<vluquez@agro.unlp.edu.ar>.

${ }^{4}$ Universidad Nacional de La Plata, INIFIVE-CONICET, Argentina. E-mail: <smonteoliva@ yahoo.com.ar>.

*Corresponding author.
}

\begin{abstract}
A short rotation intensive system with willows was analyzed with the following aims: a - to determine the effects of irrigation, genotype and plantation density on wood anatomy, wood density, moisture content, lower heating value, total ash content and energy accumulated in the woody biomass; $b$ - to explore the relationships between anatomical and physical wood properties and the parameters determining their quality as a biofuel. A complete factorial experiment was set up, with three factors and two levels for each factor. The factors were: irrigation, plantation density and clone (genotype). The clones were Salix matsudana Koidz. $x$ Salix alba L. 'Barrett 13-44 INTA' (B) and Salix alba L. 'Yaguareté INTA - CIEF' (Y). 46 stools of 1 $\mathrm{m}$ long were sampled, on which the following determinations were carried out: vessel diameter and frequency, fiber wall thickness and area, wood density, moisture content, ash content and heating values. Clone B had higher wood density than clone $\mathrm{Y}\left(0.406 \mathrm{vs} .0 .395 \mathrm{~g} / \mathrm{cm}^{3}\right)$ and lower moisture content $(47.11 \mathrm{vs} .50 .53 \%)$. The plantation density did not affect any of the variables analyzed. Irrigation increased the energy yield to $393.2 \mathrm{Gj} / \mathrm{ha}$, compared to $309.15 \mathrm{Gj} / \mathrm{ha}$ without irrigation. A system with clone B planted at a lower density $(13,000$ plants/ha) and under irrigation has the best advantage as an energetic crop over the other alternatives evaluated in this work.
\end{abstract}

Keywords: Wood; Heating values; Silviculture

\section{EFEITO DA IRRIGAÇÃO, DENSIDADE DE PLANTIO E COMPOSIÇÃO CLONAL EM PARÂMETROS DE QUALIDADE DE BIOMASSA LENHOSA PARA BIOENERGIA EM UM SISTEMA DE CURTA ROTAÇÃO COM SALGUEIROS (Salix spp.)}

\begin{abstract}
RESUMO - Em um plantio de salgueiro manejado em um sistema de curta rotação estudou o efeito da composição clonal, densidade de plantação e irrigação suplementar sobre anatomia da madeira, densidade, teor de umidade, poder calorífico inferior, teor de cinzas e a energia acumulada na biomassa lenhosa, e também estabeleceu as associações entre características anatômicas e físicas da madeira e os parâmetros que determinam a sua qualidade como combustível. Um experimento fatorial completo com três fatores foi estabelecido: irrigação, densidade de plantação e clone, cada um com dois níveis. Os clones foram: Salix matsudana Koidz. x Salix alba L. 'Barrett 13-44 INTA' (B), e Salix alba L. 'Yaguareté INTA - CIEF'( $Y)$. Foram amostrados 46 varas de $1 \mathrm{~m}$ de comprimento para determinações anatomia (diâmetro e frequência do vasos, a espessura da parede da fibra e a área ocupada de parede), densidade da madeira, teor de umidade, cinza e variáveis energéticas. O clone $B$ foi ligeiramente mais elevado do que o clone de $Y$, tendo maior densidade da madeira

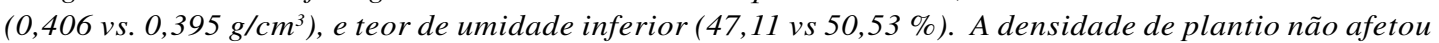
nenhuma das variáveis analisadas, mas a irrigação suplementar teve influência sobre a eficiência energética
\end{abstract}


(393,2 vs. 309,15 Gj/ha sem irrigação). Um sistema de produção implementado com o clone B, com menor densidade de plantio (13.000 plantas / ha) e cultivada com irrigação apresenta vantagens energéticas em relação a outras combinações avaliadas.

Palavras-Chave: Madeira, Poder calorífico, Silvicultura

\section{INTRODUCTION}

The use of short rotation intensive culture systems (SRIC) is an efficient way to produce biomass for energy. The SRIC system involves the establishment of plantations using genetically improved materials, vegetative propagated materials and high plantation densities (1,500 to 28,000 plants/ha) (Tharakan et al., 2003; Njakou Djomo et al., 2015). Willows (Salix spp.) growing in such systems have a significant potential for energy production worldwide (Klansja et al., 2002). SRIC systems with willows can be set up with different clones, plantation densities and rotation cycle lengths; and other treatments like irrigation and ferti - irrigation can also be applied. These factors are combined with the aim of maximizing the energy yield per unit area (Njakou Djomo et al., 2015), which is related to both biomass yield and its quality as an energy source.

In Argentina, renewable energy sources based on biomass represent only $5 \%$ of the primary energetic matrix (Achinelli et al., 2016). During the last decade, the country increased the amount of imported fossil fuels, as a consequence of the reduction in the national reserves. This fact sparked the interest of the Government and of private companies in developing the use of woody biomass to generate energy through firing and co-firing processes. An important drawback to this development is the scarcity of information on the productivity of SRIC systems under local conditions and on the quality of the biomass produced for the generation of energy (Achinelli et al., 2016).

Several traits have an effect on biomass quality for bioenergy generation, among them are moisture content, wood density, heating values and ash content (Tharakan et al., 2003; Cardoso et al., 2015). The biomass that provides better results for energy generation has low moisture and ash content, and high wood density and heating value (Labrecque et al., 1997; Klansja et al., 2002; Eloy et al., 2014). Wood density is routinely used as a quality index for different industrial uses in breeding programs (Raymond, 2002). Additionally, wood density relates different anatomical features such as size and quantity of vessels to the amount, quality and dimensions of fibers (Sette Jr. et al., 2012; Berthod et al., 2015).

Several factors can modify the anatomical structure and properties of the wood, among them are genetics (origin, clone), silvicultural practices (irrigation, fertilization) and the environment (soil, temperature, rainfall) (Raymond, 2002; Tharakan et al., 2005). In SRIC systems, genotype, plantation density, rotation length and management practices can influence both wood yield and quality, affecting its ability to generate energy (Labrecque et al., 1997; Tharakan et al., 2003, 2005; Eloy et al., 2014). Willows can adapt to water availability by modifying their hydraulic conductivity, biomass partition, photosynthetic capacity and size and number of xylem vessels (Wikberg and Ögren, 2004, 2007; Ogasa et al., 2013). Doffo et al. (2017a) analyzed the response of the clones used in this work to alternate episodes of drought and flooding. The wood generated by both clones during drought had vessels with smaller diameter and higher frequency (Doffo et al., 2017a).

In this work, a SRIC system with willows was analyzed with the following aims: a - to determine the effects of genotype, plantation density and irrigation on wood anatomy, wood density, moisture content, heating values and energy content of the biomass; and $b$ - to determine if there are associations between physical and anatomical wood traits and the parameters determining their quality as a biofuel.

\section{MATERIALS AND METHODS}

This work was based on material from a SRIC field plantation located at the "Julio Hirschhorn" Experimental Station, Faculty of Agricultural and Forest Sciences, National University of La Plata, in Los Hornos, Buenos Aires, Argentina (3459'09' S; 5759' 42'” W). The plantation took place between August and September of 2012 (Doffo et al., 2017b). 24 experimental units of 56 plants were arranged in a three-block, split-splitplot layout. Eight treatments were evaluated, which resulted from the combination of three factors with

Revista Árvore. 2018;42(2):e420210 
two levels. Each block was divided in two main plots according to the irrigation treatment (rain fed vs. drip irrigation), and separated by a $4 \mathrm{~m}$ strip to avoid lateral movement of water from irrigated to rain fed plots. The main plots were divided into two sub-plots according to plantation density: low density $(13,333$ plants/ha configured in a $1 \mathrm{~m} \times 0.75 \mathrm{~m}$ plantation frame) and high density (20,000 plants/ha, in a $1 \mathrm{~m}$ x $0.5 \mathrm{~m}$ plantation frame). Each sub-plot was further divided into two subsub-plots according to genotype: Salix matsudana Koidz. x Salix alba L. 'Barrett 13-44 INTA' (clone B), or Salix alba L. 'Yaguareté INTA CIEF' (clone Y). The blocks, main-plots, sub-plots and sub-sub-plots were separated by a border of clone Salix babylonica x Salix alba L. 'Ragonese 131-25 INTA'.

The plants were harvested and measured the following season (2013-2014), thus the rotation length extended for a year. The harvest was carried out manually during the non-growing season (winter). Stools from two plants of the central part of each sub-sub-plot were sampled. From each stool, a piece of $1 \mathrm{~m}$ long was cut at $0.30 \mathrm{~cm}$ from the soil. A $15-\mathrm{cm}$-long subsample without bark (core) containing secondary xylem was obtained from the basal part. Different variables were measured on these cores: physical (moisture content, basic wood density) and anatomical (fiber wall thickness, fiber wall area, vessel diameter and frequency). The anatomical variables were measured on the entire transverse sections of the core, stained with safranin and mounted in water for observation with an Olympus optical microscope (40x, 200x and 400x). The digital images were taken with a Lumenera camera connected to the microscope, and measured with the software ImagePro.

Vessel number and diameter were automatically determined on the transverse section, on five 40x images. Fiber wall thickness was measured manually as the distance (in $\mu \mathrm{m}$ ) between the lumen of two contiguous fibers (double wall/2) on five images per clone and treatment at 200x ( $n=100$ for each image). Fiber wall area $(\%)$ was measured as fiber wall area/total area, in three fiber sectors on each of the five images used to determine wall thickness. The physical variables were determined on the de-barked cores after the histological analysis was carried out. The cores were saturated with water for a week. The saturated volume was determined by fluid displacement, and the saturated weight was determined afterwards. To measure the anhydrous weight, the cores were oven-dried at $103 \pm 2$ ${ }^{\circ} \mathrm{C}$ until constant weight. Basic wood density $\left(\mathrm{g} / \mathrm{cm}^{3}\right)$ was calculated as the ratio between anhydrous weight and saturated volume. The initial moisture content on wet basis (\%) was determined as the saturated weight minus the anhydrous weight divided by the saturated weight. The values of the two individuals per subsub-plot were averaged for a total of $n=24$. Afterwards, the total above-ground biomass of the other 22 plants of each sub-sub-plot were harvested to obtain the anhydrous biomass yield (oven-dried at $105^{\circ} \mathrm{C}$, in $\mathrm{MG} /$ ha), as described in Doffo et al. (2007b). An aliquot of this material was air-dried and chipped into $2-3 \mathrm{~cm}$ pieces with a commercial chipper. From these chips, a sample was taken and subsequently grinded to 1 $\mathrm{mm}$ pieces with a grinder (Thomas-Wiley Laboratory Mill, Model 4, Thomas Scientific EEUU). The upper heating values (data not shown) and ash content were determined at the laboratories of the INTA EEA in Pergamino. The upper heating value was measured with a constant volume calorimeter (cal/g; Castro et al., 1999); and the percentage of ash on dry basis was determined with the AOAC 942.05 method. The lower heating value $(\mathrm{cal} / \mathrm{g}$ ) was calculated from the upper heating value according to Owens and Cooley (2013); and for the hydrogen content (\%), the published values for Salix wood were used (Waliszewska et al., 2006). The energetic yield for each treatment $(\mathrm{Gj} / \mathrm{ha})$ was estimated from the lower heating value and the biomass data for this season published in Doffo et al. (2017b) according to:

$$
\mathrm{EY}(\mathrm{Gj} / \mathrm{ha})=\mathrm{B}(\mathrm{Mg} / \mathrm{ha}) \times \mathrm{LHV}(\mathrm{Mj} / \mathrm{kg})
$$

$\mathrm{EY}=$ Energetic Yield expressed in Gigajoules per hectare.

$\mathrm{B}=$ Biomass with bark, anhydrous (oven-dried at $105^{\circ} \mathrm{C}$ ) in Megagrams per hectare.

LHV $=$ Lower Heating Value in Megajoules per kilogram of biomass with anhydrous bark.

The statistical analysis was carried out using the INFOSTAT package (InfoStat, 2008). The normal distribution of the variables was checked with the Kolmogorov-Smirnov test and the homogeneity of variances with the Levene test. An ANOVA with four fixed factors was carried out to determine the sources of variation (clone, block, irrigation, plantation density). The mean comparisons were made using the Tukey test $(\mathrm{p}<0.05)$. The relationship between the different

Revista Árvore. 2018;42(2):e420210 
variables (anatomical, physical and energetic) was determined using the Pearson correlation coefficient $(\mathrm{n}=24, \mathrm{p}<0.05)$.

\section{RESULTS}

\subsection{Effects of plantation density and irrigation}

The ANOVA indicated that plantation density did not have any significant effects on the measured variables; neither did the interaction between plantation density and clone (Table 1). On the other hand, irrigation had a significant effect on energetic yield and a marginally significant effect on ash content $(0.05<\mathrm{p}<0.1)$ (Table 1$)$. Irrigated plots had the lowest ash content and higher energy, notwithstanding clone and plantation density (Table 2, Fig. 1). However, there were interactions between irrigation and density that were significant for moisture content but marginally significant for vessel diameter (Table 1).

\subsection{Genotype effects}

The genotype was a significant factor for basic wood density and moisture content (Table 1). Clone Y had lower wood density and higher moisture content than clone B (Table 2, Fig. 1). The genotype had a marginal effect on ash content and vessel diameter, both showing higher values in clone Y (Table 2, Fig. 1).

\subsection{Variability of wood properties and energetic variables}

Wood density varied according to clone, irrigation and plantation density, with a significant interaction for clone $\mathrm{x}$ irrigation $\mathrm{x}$ density. Plots of clone $\mathrm{B}$ with irrigation and low plantation density had the highest wood density $\left(0.422 \mathrm{~g} / \mathrm{cm}^{3}\right)$, but they differed significantly only from clone $\mathrm{Y}$, with no irrigation and high plantation density $\left(0.385 \mathrm{~g} / \mathrm{cm}^{3}\right)$ (Table 2 , Fig. 1$)$. The moisture content had an inverse relationship with the wood basic density. The moisture content of clone Y $(50.5 \%)$ was significantly higher than that of clone B $(47.1 \%)$. The management practices had a different effect, with a significant interaction for irrigation $\mathrm{x}$ density. There was a trend for higher moisture content in the low density and irrigated treatment $(50 \%)$ and high density without irrigation (49\%) in both clones (Table 2, Fig. 1), albeit there was no significant difference according to the Tukey test. There were also trends for the total ash content ( $p<0.1$, Table 1$)$. The ash content of wood (including bark) of clone $\mathrm{Y}$ was slightly higher than in clone B (2.11\% vs. $1.98 \%)$. In addition to that, irrigated plants had lower ash content that rain fed plants (1.96 $\%$ vs. $2.13 \%$ ) (Table 2, Fig. 1).

The energetic yield is a variable which depends on the total biomass per hectare (data not shown), and on the lower heating value of the biomass. In this work, the lower heating values varied between 4293.8 and $4410.1 \mathrm{cal} / \mathrm{g}$ (Table 2, Fig. 1) and were not affected by any of the factors tested (Table 1). As a consequence, the significant differences in energetic yield between irrigated and rain fed plots (393.2 $\mathrm{Gj} / \mathrm{ha}$ vs. 309.15 Gj/ha) were caused mainly by differences in biomass yield.

The only anatomical variable affected by the factors tested was vessel diameter, which changed according to the clone ( $45.33 \mu \mathrm{m}$ clone $\mathrm{Y} ; 43.96 \mu \mathrm{m}$ clone $\mathrm{B}$ ), and to the interactions clone $\mathrm{x}$ irrigation and density $\mathrm{x}$ irrigation (Tables 1 and 2, Fig. 1). The other variables were not affected by the factors analyzed in this experiment.

\subsection{Correlation between variables}

Energetic yield had a positive correlation with wood density $(r=0.41)$, while lower heating value did not

Table 1 - ANOVA significances and $p$ values.

Tabela 1 - ANAVA significância de valores $p$.

\begin{tabular}{|c|c|c|c|c|c|c|c|c|c|}
\hline Factors & $\begin{array}{c}\text { Basic } \\
\text { Wood } \\
\text { Density }\end{array}$ & $\begin{array}{l}\text { Moisture } \\
\text { Content }\end{array}$ & Ash & Yield & $\begin{array}{c}\text { Lower } \\
\text { Heating } \\
\text { Value }\end{array}$ & Diameter & Frequency & $\begin{array}{l}\text { Fiber } \\
\text { Wall } \\
\text { Area }\end{array}$ & $\begin{array}{c}\text { Fiber } \\
\text { Wall } \\
\text { Thickness }\end{array}$ \\
\hline Irrigation & $\mathrm{ns}$ & $\mathrm{ns}$ & $0,081^{\mathrm{ms}}$ & $0,001 * *$ & $\mathrm{~ns}$ & $\mathrm{~ns}$ & $\mathrm{~ns}$ & $\mathrm{~ns}$ & ns \\
\hline P. $\mathrm{D}^{1}$ & $\mathrm{~ns}$ & $\mathrm{~ns}$ & ns & $\mathrm{ns}$ & $\mathrm{ns}$ & $\mathrm{ns}$ & $\mathrm{ns}$ & $\mathrm{ns}$ & $\mathrm{ns}$ \\
\hline Clone & $0,047 *$ & $0,034 *$ & $0,056^{\mathrm{ms}}$ & ns & $\mathrm{ns}$ & $0,051^{\mathrm{ms}}$ & $\mathrm{ns}$ & $\mathrm{ns}$ & ns \\
\hline P.D $x$ irrigation & ns & $0,038 *$ & ns & ns & $\mathrm{ns}$ & $0,084^{\mathrm{ms}}$ & $\mathrm{ns}$ & ns & ns \\
\hline Clone x P.D & $\mathrm{ns}$ & ns & $\mathrm{ns}$ & ns & $\mathrm{ns}$ & ns & $\mathrm{ns}$ & $\mathrm{ns}$ & ns \\
\hline Clone $\mathrm{x}$ irrigation & $\mathrm{ns}$ & $\mathrm{ns}$ & ns & $\mathrm{ns}$ & $\mathrm{ns}$ & $0,011 *$ & $\mathrm{~ns}$ & $\mathrm{~ns}$ & $\mathrm{~ns}$ \\
\hline Clone $x$ P.D $x$ irrigation & $0,024 *$ & ns & ns & ns & $\mathrm{ns}$ & ns & $\mathrm{ns}$ & ns & ns \\
\hline
\end{tabular}

${ }^{1}$ P.D: plantation density, significant $p$ values: $* * 1 \%, * 5 \%,{ }^{\mathrm{ms}} 10 \%$ (marginally significant), ns: non-significant

Revista Árvore. 2018;42(2):e420210 
Table 2 - Average values ( \pm Standard deviation) of the variables in the different evaluated treatments. Tabela 2 - Os valores médios ( \pm desvio padrão) das variáveis nas diferentes tratamentos avaliados.

\begin{tabular}{|c|c|c|c|c|c|c|c|c|c|c|c|}
\hline Clone & $\begin{array}{c}\text { Plantation } \\
\text { Density }\end{array}$ & Irrigation & $\begin{array}{c}\text { Basic } \\
\text { Wood } \\
\text { Density }\end{array}$ & Moisture & $\begin{array}{c}\text { Total } \\
\text { Ash } \\
\text { Content }\end{array}$ & $\begin{array}{c}\text { Energetic } \\
\text { Yield }\end{array}$ & $\begin{array}{c}\text { Lower } \\
\text { Heating } \\
\text { Value }\end{array}$ & $\begin{array}{c}\text { Vessel } \\
\text { Diameter }\end{array}$ & $\begin{array}{c}\text { Vessel } \\
\text { Frequency }\end{array}$ & $\begin{array}{l}\text { Fiber } \\
\text { Wall } \\
\text { Area }\end{array}$ & $\begin{array}{c}\text { Fiber } \\
\text { Wall } \\
\text { Thickness }\end{array}$ \\
\hline \multirow{5}{*}{$\mathrm{Y}$} & & & $\left(\mathrm{g} / \mathrm{cm}^{3}\right)$ & $(\%)$ & $(\%)$ & (Gj/ha) & (cal/g) & $(\mu \mathrm{m})$ & $\left(\mathrm{mm}^{-2}\right)$ & $(\%)$ & $(\mu \mathrm{m})$ \\
\hline & LD & I & $\begin{array}{l}0.397 \mathrm{ab} \\
\pm 0.031\end{array}$ & $\begin{array}{l}47 \mathrm{a} \\
\pm 2\end{array}$ & $\begin{array}{l}2.13 \mathrm{a} \\
\pm 0.12\end{array}$ & $\begin{array}{l}406.4 \mathrm{~b} \\
\pm 46.4\end{array}$ & $\begin{array}{c}4300.2 \mathrm{a} \\
\pm 53.2\end{array}$ & $\begin{array}{c}48,08 \mathrm{~b} \\
\pm 1,90\end{array}$ & $\begin{array}{l}77 \text { a } \\
\pm 21\end{array}$ & $\begin{array}{c}66 \text { a } \\
\pm 2\end{array}$ & $\begin{array}{l}2.00 \mathrm{a} \\
\pm 0.13\end{array}$ \\
\hline & LD & NI & $\begin{array}{c}0.396 \mathrm{ab} \\
\pm 0.015\end{array}$ & $\begin{array}{c}52 \mathrm{a} \\
\pm 3\end{array}$ & $\begin{array}{l}2.07 \mathrm{a} \\
\pm 0.09\end{array}$ & $\begin{array}{c}313.2 \mathrm{ab} \\
\pm 66.8\end{array}$ & $\begin{array}{c}4337.9 \mathrm{a} \\
\pm 22.5\end{array}$ & $\begin{array}{c}43,72 \mathrm{ab} \\
\pm 1,96\end{array}$ & $\begin{array}{l}89 a \\
\pm 21\end{array}$ & $\begin{array}{l}69 \mathrm{a} \\
\pm 5\end{array}$ & $\begin{array}{l}2.14 \mathrm{a} \\
\pm 0.16\end{array}$ \\
\hline & HD & I & $\begin{array}{c}0,403 \mathrm{ab} \\
\pm 0.024\end{array}$ & $\begin{array}{c}54 \mathrm{a} \\
\pm 4\end{array}$ & $\begin{array}{l}2.03 \mathrm{a} \\
\pm 0.27\end{array}$ & $\begin{array}{c}398.1 \mathrm{ab} \\
\pm 33.9\end{array}$ & $\begin{array}{c}4340.5 \mathrm{a} \\
\pm 46.9\end{array}$ & $\begin{array}{c}46,61 \mathrm{ab} \\
\pm 1,38\end{array}$ & $\begin{array}{c}89 a \\
\pm 3\end{array}$ & $\begin{array}{l}72 \mathrm{a} \\
\pm 2\end{array}$ & $\begin{array}{l}2.27 \mathrm{a} \\
\pm 0.17\end{array}$ \\
\hline & HD & NI & $\begin{array}{l}0.385 \mathrm{a} \\
\pm 0.005\end{array}$ & $\begin{array}{c}49 a \\
\pm 4\end{array}$ & $\begin{array}{l}2.35 \mathrm{a} \\
\pm 0.06\end{array}$ & $\begin{array}{l}318.8 \mathrm{ab} \\
\pm 16.8\end{array}$ & $\begin{array}{c}4326.5 \mathrm{a} \\
\pm 46.4\end{array}$ & $\begin{array}{c}43,57 \mathrm{ab} \\
\pm 2,47\end{array}$ & $\begin{array}{c}93 \mathrm{a} \\
\pm 7\end{array}$ & $\begin{array}{l}71 \mathrm{a} \\
\pm 10\end{array}$ & $\begin{array}{l}1.99 \mathrm{a} \\
\pm 0.36\end{array}$ \\
\hline \multirow{4}{*}{ B } & LD & I & $\begin{array}{l}0.422 b \\
\pm 0.018\end{array}$ & $\begin{array}{c}47 a \\
\pm 3\end{array}$ & $\begin{array}{l}1.89 \mathrm{a} \\
\pm 0.20\end{array}$ & $\begin{array}{c}406.4 \mathrm{~b} \\
\pm 34.4\end{array}$ & $\begin{array}{c}4318.5 \mathrm{a} \\
\pm 25.5\end{array}$ & $\begin{array}{c}45,14 \mathrm{ab} \\
\pm 3,83\end{array}$ & $\begin{array}{l}91 \mathrm{a} \\
\pm 8\end{array}$ & $\begin{array}{c}73 \mathrm{a} \\
\pm 2\end{array}$ & $\begin{array}{l}2.03 \mathrm{a} \\
\pm 0.01\end{array}$ \\
\hline & LD & NI & $\begin{array}{c}0.395 \mathrm{ab} \\
\pm 0.021\end{array}$ & $\begin{array}{c}49 a \\
\pm 3\end{array}$ & $\begin{array}{l}2.08 \mathrm{a} \\
\pm 0.39\end{array}$ & $\begin{array}{c}283.5 \mathrm{a} \\
\pm 9.3\end{array}$ & $\begin{array}{c}4345.9 \mathrm{a} \\
\pm 22.8\end{array}$ & $\begin{array}{c}43,57 \mathrm{ab} \\
\pm 2,37\end{array}$ & $\begin{array}{l}93 a \\
\pm 7\end{array}$ & $\begin{array}{l}71 \mathrm{a} \\
\pm 4\end{array}$ & $\begin{array}{l}1.95 \mathrm{a} \\
\pm 0.06\end{array}$ \\
\hline & HD & I & $\begin{array}{c}0.402 \mathrm{ab} \\
\pm 0.013\end{array}$ & $\begin{array}{c}46 a \\
\pm 2\end{array}$ & $\begin{array}{l}1.80 \mathrm{a} \\
\pm 0.17\end{array}$ & $\begin{array}{c}361.7 \mathrm{ab} \\
\pm 17.3\end{array}$ & $\begin{array}{c}4293.9 \mathrm{a} \\
\pm 27.9\end{array}$ & $\begin{array}{r}40,61 \mathrm{a} \\
\pm 0,18\end{array}$ & $\begin{array}{l}82 a \\
\pm 14\end{array}$ & $\begin{array}{l}71 \mathrm{a} \\
\pm 2\end{array}$ & $\begin{array}{l}2.08 \mathrm{a} \\
\pm 0.06\end{array}$ \\
\hline & HD & NI & $\begin{array}{c}0.403 \mathrm{ab} \\
\pm 0.023\end{array}$ & $\begin{array}{c}46 a \\
\pm 2\end{array}$ & $\begin{array}{l}2.02 \mathrm{a} \\
\pm 0.04\end{array}$ & $\begin{array}{c}321.1 \mathrm{ab} \\
\pm 45.3\end{array}$ & $\begin{array}{c}4410.2 \mathrm{a} \\
\pm 161.9\end{array}$ & $\begin{array}{c}45,27 \mathrm{ab} \\
\pm 1,69\end{array}$ & $\begin{array}{l}90 a \\
\pm 9\end{array}$ & $\begin{array}{l}72 \mathrm{a} \\
\pm 3\end{array}$ & $\begin{array}{l}2.01 \mathrm{a} \\
\pm 0.14\end{array}$ \\
\hline
\end{tabular}

Y: clone Yaguareté, B: clone Barrett, LD: lower planting density, HD: higher planting density, I: with irrigation, NI: without irrigation. Letters should be read vertically, and indicate significant differences according to the Tukey test $(p<0.05)$

correlate with any variable $(p>0.5)$. Ash content had a negative association with wood density $(r=-0.52)$. The anatomical variables did not correlate significantly with neither density nor energetic variables $(p>0.5)$.

\section{DISCUSSION}

\subsection{Effects of plantation density and irrigation}

Plantation density as main factor did not affect any of the measured variables. On the other hand, irrigation had a significant effect on energetic yield. However, there were interactions between irrigation and plantation density; these being significant for moisture content and marginally significant for vessel diameter (Table 1).

For the same clones (Y and B), Doffo et al. (2017a) detected differences in vessel anatomy in response to different sequences of drought and flooding episodes. The wood produced by both clones under drought had smaller vessels with higher frequency, which lead to a lower xylem hydraulic conductivity. These results are in coincidence with the data of the present work regarding the irrigated treatment.

As a whole, the results are similar to the data reported for willows and other species under SRIC cultivation. Eloy et al. (2014) found that plantation density did not have a significant effect, neither on heating values nor on wood density, in four forest species (Eucalyptus and Acacia) at any age ( 1 to 3 years). Labrecque et al. (1997) determined that plantation density did not affect upper heating values, ash content or combustion index in three Salix species cultivated under SRIC.

\subsection{Genotype effects}

The genotype was a significant factor for wood density and moisture content, but the influence was marginal on ash content and vessel diameter. The clone $\mathrm{x}$ irrigation interaction and the triple interaction modified wood density and vessel diameter (Table 1). These results are similar to the data reported in previous works. Salix genotypes had different values for wood density, moisture content, ash content and heating values, as a result of small differences in anatomy and chemical composition during xylem development (Labrecque et al., 1997; Klansja et al., 2002; Tharakan et al., 2003; Cardoso et al., 2015). In our case, the data corresponding to the chemical composition of the wood (as cellulose, lignin and extractives) are not available; therefore, it is not possible to determine if the differences between clones are due to these main chemical components. The difference found in vessel diameter seems to be insufficient to explain the variation in wood density and moisture content in the clones. This is confirmed by the analysis of the relationship between variables. Wood anatomy did not correlate with any variable, 

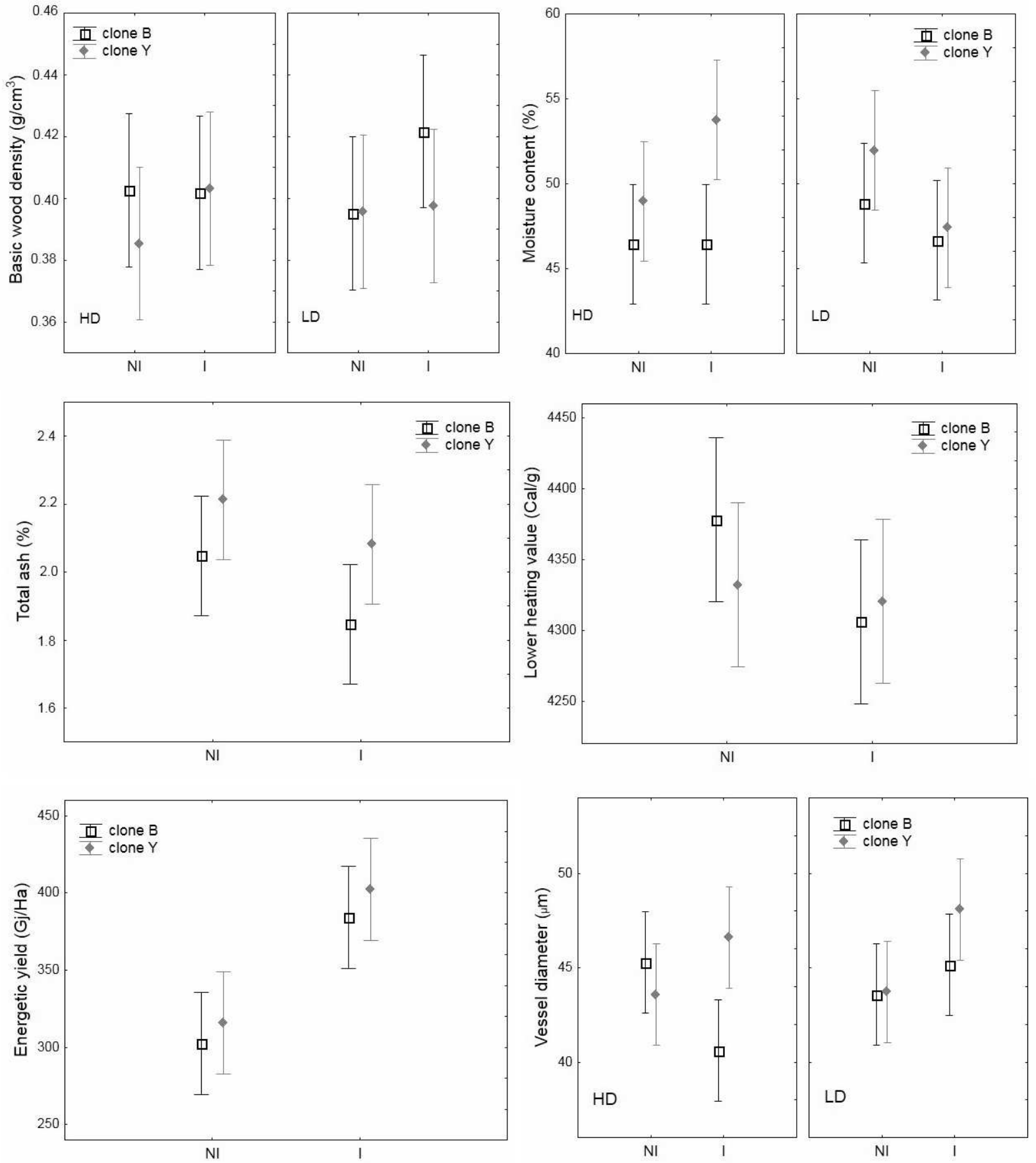

Figure 1 - Average values and confidence intervals for wood basic density, moisture content, ash content, lower heating values, energy, and vessel diameter, according to clone and silvicultural treatments. Clone Y: Yaguareté, clone B: Barrett, I: with irrigation, NI: without irrigation, LD: lower plantation density, HD: higher plantation density.

Figura 1 - Os valores meios (e os intervalos de confiança) para as variáveis de densidade, o conteúdo de umidade, cinza total, poder calorífico inferior, energia e o diâmetro dos vasos de acordo com o clone e silvicultura. clone Y: Yaguareté, clone B: Barrett, I: com irrigação, NI: sem irrigação, BD: plantação de baixa densidade, AD: plantação de alta densidade.

Revista Árvore. 2018;42(2):e420210 
and neither did the heating values. According to previous works, wood density did not have a direct effect on heating values (Gravalos et al., 2016). The amount of lignin and extractives (especially in organic solvents) are the main chemical components that increase the heating value (Zanuncio et al., 2014; Gravalos et al., 2016), while the amount of cellulose and ashes have a negative effect upon this parameter.

Doffo et al. (2017a) reported differences in vessel anatomy for clones $\mathrm{B}$ and $\mathrm{Y}$ in experiments which applied episodes of flooding and drought stress. Both genotypes had structural and physiological differences and also differed in their sensibilities to water stress, with clone B being susceptible to flooding (Cerrillo et al., 2013). Clone $\mathrm{Y}$ was more sensitive to drought, reacting with an extensive defoliation and reducing stomatal conductance and xylem hydraulic conductivity; while clone B was affected to a lesser extent (Doffo et al., 2017a). Clone $\mathrm{Y}$ had vessels with higher diameter and lower frequency than clone B. These data are similar to the results found in this work, showing that both clones are differentially affected by these short-term stress episodes (15 to 40 days).

The values for wood density, moisture and ash content found in this work are similar to previously reported values, depending on the genotype and the age of the material (Labrecque et al., 1997; Klansja et al., 2002; Tharakan et al., 2003, 2005; Cardoso et al., 2015). For different Salix species aged from 1 to 3 years, these authors found that wood density ranged between 0.340 to $0.480 \mathrm{~g} / \mathrm{cm}^{3}$, moisture content varied between 50 to $58 \%$ and ash content between 0.89 to $2.6 \%$.

\section{CONCLUSIONS}

As the results of this work have shown, clone B had a slightly better performance than clone $\mathrm{Y}$ as a bioenergy crop cultivated in a SRIC system with a one-year rotation. This was because clone B produced wood with higher density and less moisture content than clone Y. Plantation density had no effect on the energetic variables (energetic yield and heating value) but irrigation did.

Summarizing, a SRIC system with clone B planted at low density (13,000 plants/ha) and under irrigation has the best advantages as an energetic crop over the other alternatives evaluated in this work.

\section{AKNOWLEDGMENTS}

This work was funded by the Ministry of Agroindustry to VL, PIA 10007.

\section{REFERENCES}

Achinelli F, Doffo G, Etchevers P, Luquez V. A Salix spp. short rotation coppice system in Buenos Aires, Argentina: effects of clonal composition, planting density and drip irrigation on biomass production. Abstracts of the $25^{\circ}$ Session of the International Poplar Comission. Berlin: 2016. p.107.

Berthod N, Brereton NJB, Pitre FE, Labrecque M. Five willow varieties cultivated across diverse field environments reveal stem density variation associated with high tension wood abundance. Frontiers in Plant Science. 2015;6:948.

Cardoso MB, Ladio AH, Dutrus SM, Lozada M. Preference and calorific value of fuelwood species in rural populations in northwestern Patagonia. Biomass and Bioenergy. 2015;81:514-20.

Castro R, Suárez J, Eimil FM. Evaluación del poder calorífico superior en biomasa. Investigación Agraria. Sistemas y Recursos Forestales. 1999;8(1):129-38.

Cerrillo T, Rodriguez ME, Achinelli F, Doffo G, Luquez VMC. Do greenhouse experiments predict willow responses to long-term flooding events in the field? Bosque. 2013;34:71-9.

Doffo G, Monteoliva SE, Rodríguez ME, Luquez VM. Physiological responses to alternative flooding and drought stress episodes in two willows (Salix spp.) clones. Canadian Journal of Forest Research. 2017a;47:174-82.

Doffo G, Achinelli F, Rodríguez ME, Luquez VM. Rendimiento de un sistema de rotación corta de alta densidad en Buenos Aires, Argentina. Bosque. 2017b;38:587-92.

Eloy E, Caron BO, Agostinho da Silva D, Schmidt D, Trevisan R, Behling A, et al. Influência do espaçamento nas características energéticas de espécies arbóreas em plantios de curta rotação. Revista Árvore. 2014;38(3):551-9. 
Gravalos I, Xyradakis P, Kateris D, Gialamas T, Bartzialis D, Giannoulis K. An experimental determination of gross calorific value of different agroforestry species and bio-based industry residues. Natural Resources. 2016;7:57-68.

INFOSTAT. Manual de usuario, Versión 2008. Grupo InfoStat, FCA, Universidad Nacional de Córdoba; 2008. 334p.

Klansja B, Kopitovic S, Orlovic S. Wood and bark of some poplar and willow clones as fuelwood. Biomass and Bioenergy. 2002;23:427-32.

Labrecque M, Teodorescu TI, Daigle S. Biomass productivity and wood energy of Salix species after two years growth in SRIC fertilized with wastewater sludge. Biomass and Bioenergy. 1997;12(6):409-17.

Njakou Djomo SAC, Zenone T, De Groote T, Bergante S, Facciotto G, Sixto H, et al. Energy performances of intensive and extensive short rotation cropping systems for woody biomass production in the EU. Renewable and Sustainable Energy Reviews. 2015;1:845-54.

Ogasa M, Miki NH, Murakami Y, Yoshikawa K. Recovery performance in xylem hydraulic conductivity is correlated with cavitation resistance for temperate deciduous tree species. Tree Physiology. 2013;33:335-44.

Owens E, Cooley S. Calorific value of Irish woodfuels. Cofor Connects Notes - Processing / Products. 2013;32(1-8). Available in: ttp:// www.woodenergy.ie/media/woodenergy/content/ woodfuelsstovesandboilers/PP32.pdf

Raymond CA. Genetics of Eucalyptus wood properties. Annals of Forest Science. 2002;59(56):525-31.

Sette Jr CR, Oliveira RI, Tomazello Filho M, Minoru Yamaji F, Laclau JP. Efeito da idade e posição de amostragem na densidade e características anatômicas da madeira de Eucalyptus grandis. Revista Árvore. 2012;36(6):1183-90.

Tharakan PJ, Volk TA, Abrahamson LP, White EH. Energy feedstock characteristics of willow and hybrid poplar clones at harvest age. Biomass and Bioenergy. 2003;25:571-80.

Tharakan PJ, Volk TA, Nowak CA, Abrahamson L. Morphological traits of 30 willow clones and their relationship to biomass production. Canadian Journal of Forest Research. 2005;35:421-31.

Waliszewska B, Zborowska M, Pradzynski W, Kominer A. Chemical composition and gross calorific value of selected Salix hybrids. Wood structure and properties. Slovakia: Arbora Publishers, 2006. p.171-3.

Wikberg J, Ögren E. Interrelationships between water use and growth traits in biomass-producing willows. Trees. 2004; 18:70-6.

Wikberg J, Ögren E. Variation in drought resistance, drought acclimation and water conservation in four willow cultivars used for biomass production. Tree Physiology. 2007;27:1339-46.

Zanuncio AJV, Carvalho AG, Trugilho PF, Campos T, Monteiro T. Extractives and energetic properties of wood and charcoal. Revista Árvore. 2014;38(2):369-74.

Revista Árvore. 2018;42(2):e420210 